переувлажняется. По этой причине прирост деревьев здесь испытывает угнетение (выявляется отрицательная корреляция с суммой осадков за год и с суммой осадков за вегетационный период, табл. 1). При отсутствии горизонта ортштейна сосна могла бы испытывать дефицит влаги в почве, так как ниже залегают водопроницаемые рыхлые породы - песок, который здесь часто оказывается дренированным. В таких условиях произрастает модельное дерево 3, которое имеет положительную корреляцию со среднегодовой температурой (табл. 1).

Можно с большой достоверностью сказать, что в условиях Выксунских сосновых боров, произрастающих на низких террасах, происходит частая сменяемость фациальных условий, и в пределах каждой отдельной фации лимитирующими факторами могут являться разные климатические, почвенные, литогенные, гидроморфные, биотические компоненты ландшафта.

Условия Окско-Тешинского зандрового полесья в целом являются благоприятными для роста сосны обыкновенной. Отсутствие здесь сильных лимитирующих рост факторов приводит к многовариантности отклика деревьев на исходные условия произрастания, выражающиеся в особенностях их радиального прироста. В процессе данного исследования удалось найти эмпирические закономерности связи индексов прироста сосны обыкновенной с шестью рассмотренными климатическими факторами.

$$
* * *
$$

1. Битвинскас Т. Т. Дендроклиматологическис исследования. Л.: Гидрометеоиздат, 1974. 170 с.

2. Бузыкин А. И., Дашковская И. С, Черкашин В. П. Динамика радиального прироста хвойных разного ценотического положения в Приангарье//Дендроклиматология и дендрохронология. Новосибирск: Сибирск. отд. АН СССР, 1986. С. 385-389.

3. Ловелиус Н. В. Изменчивость прироста деревьев. М: Наука, 1979. 220 с.

4. Рудаков В. Е. О методике изучения влияния колебаний климата на ширину годичных колец дерева//Ботанический журнал. 1958. № 12. С. 1708-1711.

\title{
Старожилов В.Т. \\ Районирование Тихоокеанского ландшафтного пояса России как ландшафтной основы к пространственному развитию геосистемы Восточная Россия-Мировой океан
}

Дальневосточный Федеральный университет

doi: $10.18411 / 1 j-07-2021-67$

(Россия, Владивосток)

\section{Аннотация}

Работа представляет собой продолжение комплексных исследований в целом сформировавшейся ландшафтной школы профессора В.Т. Старожилова (doi:10.24411/1728-323X-2020-13079, doi:10.18411/1j-05-2020-26). Рассматривается районирование Тихоокеанского ландшафтного пояса России (doi: 10.18411/1j-01-202132), включающего Сихотэ-Алинскую, Нижнеамурскую, Камчатско-Курильскую, Сахалинскую и другие ландшафтные территории и сопряженные с ними окраинные моря. Констатируется, что на основе применения ландшафтной методологии, на основе сопряженного анализа и синтеза межкомпонентных и межландшафтных связей с учетом окраинно-континентальной дихотомии и данных по орогеническому, орографическому, климатическому и фиторастительному факторам формирования географически единых территорий в рамках горного ландшафтоведения, проведено районирование Тихоокеанского ландшафтного пояса (Российская часть) и выделены округа, провинции и области. Оно является одной из базовых моделей «фундаментом» для построения гармонизированных с природой и связанных с океаном экологических, сельскохозяйственных и других отраслевых моделей освоения, в целом пространственного развития геосистемы Восточная Россия-Мировой океан. Отмечается, что при исследовании применялись компьютерные технологии векторно- 
слоевого ландшафтного метода, которые в свою очередь создают платформу для разработки планов и проектов освоения. Они также является платформой для обучения студентов. Приводятся данные о картографической обеспеченности современными векторно-слоевыми цифровыми материалами.

Ключевые слова: районирование, провинции, области, освоение, ландшафт, пояс.

\section{Abstract}

Work is a continuation of comprehensive studies in general formed by the Landscape School of Professor V.T. Starozhilov (DOI: 10.24411 / 1728-323x-2020-13079, DOI: 10.18411 / LJ-05-2020-26). The zoning of the Pacific landscape belt of Russia (DOI: 10.18411 / LJ-01-2021-32) is considered, including Sikhote-Alin, Nizhnemur, KamchatkaKurilskaya, Sakhalin and other landscaped areas and conjugate seas. It is stated that, on the basis of the use of landscape methodology, based on the conjugate analysis and synthesis of intercompontent and intercompatinal and intercompany dichotomy and data on the orogenic, orographic, climatic and purity factors for the formation of geographically unified territories within the framework of mountain landscape, the Pacific Landscaping Belt was conducted and allocated the county, provinces and areas. They are one of the base models "foundation" to build harmonized with nature and the ocean-related environmental, agricultural and other sectoral models of development, in general, the spatial development of the Eastern Russia World Ocean. It is noted that the study used computer technology of the vector-layered landscape method, which in turn create a platform for developing plans and development projects. They are also a platform for students learning. The data on the cartographic provision of modern vector-layer digital materials are given.

Keywords: zoning, provinces, regions, development, landscape, belt.

Введение. На современном этапе развития освоения территорий Российской Федерации большое внимание уделяется освоению Восточной России. В сфере внимания есть и то, что освоение Восточной России, включающее освоение континентального обрамления и сопряженных с ним окраинных морей Тихого океана, выделяемых как Тихоокеанский ландшафтный пояс России, определяется не только базовыми экономическими, социальными и другими показателями, но и знанием ландшафтных условий территорий, прежде всего, как опорного «природного фундамента» пространственного развития территорий и, в том числе, размещения и развития конкурентоспособных технологий, фирм и т. д. (doi: 10.18411/1j-04-2021-73). Однако, по большей части обширной Восточной территории России все еще отсутствуют профессиональные современные ландшафтные исследования по ландшафтному районированию, направленные на выполнение задач освоения и практическую реализацию результатов к пространственному развитию континентального обрамления и сопряженных с ним окраинных морей (включая островные дуги - например Курильскую островную дугу) и применение картографических ландшафтных документов районирования при планировании освоения. Поэтому, в связи с освоением обширных территорий Восточной России, и встала необходимость проведения районирования. Для этого, исходя из результатов исследований ландшафтной школы профессора Старожилова, с учетом разработанных и сформулированных новых стратегий (doi: 10.24412/1728-323X-2021-2-36-43) и методологий картографирования (https://doi.org/10.24412/1816-1863-2020-4-76-83) и формирования проектов научного и прикладного освоения, Тихоокеанским ландшафтным центром ДВФУ проведено районирование Тихоокеанского ландшафтного пояса России.

При районировании применялись представления учения о таксономии районирования, рассмотренные в работах А. А. Григорьева, П. С. Макеева, Ф.Н. Милькова, Н. А. Солнцева, А. Г. Исаченко и др. Однако, общепринятой ландшафтной классификации территории России нет. Все еще не применяется наиболее значимый 
метод выявления региональных единиц по картам ландшафтно-типологических комплексов и др. В результате на схемах районирования, там где они есть, в большинстве случаев показаны ареалы, направленные на раскрытие механизма интеграции, а не фиксирование дифференциации и поиски эффектов сопряжения и внутреннего содержания таксонов на основе среднемасштабного ландшафтного картографирования. Такой подход сказался на результатах. Кроме того, не учитывались особенности глубинных корней окраинно-континентальной дихотомии в геологогеоморфологической и тектонической эволюции территории геосистемы Восточная Россия - Мировой океан, как ответственных и направляющих факторов в формировании и дифференциации ландшафтных округов, провинций и областей. Все выше отмеченное определяет актуальность выполненной работы.

Настоящие исследования по ландшафтному районированию геосистемы Восток России - Мировой океан представляют собой продолжение комплексных исследований Тихоокеанского международного ландшафтного центра ДВФУ, ландшафтной школы профессора В.Т. Старожилова, которая способна решать практические задачи по освоению территорий Тихоокеанской России и развитию теоретической базы ландшафтной георафии (https://www.dvfu.ru/expertise/news/science/landshaftnaya_shkola_professora_starozhilova/, doi:10.24411/1728-323X-2020-13079, doi:10.18411/1j-05-2020-26), работ по Тихоокеанскому ландшафтному поясу (doi:10.18411/a-2017-089), (https://doi.org/10.18411/a-2017-089), а также разработанных парадигм: общей Дальневосточной ландшафтной парадигмы и Дальневосточной ландшафтной парадигмы индикации и планирования (doi:10.18411/lj-05-2020-26), разработок по картографическому оцифрованному ландшафтному обеспечению индикации, планирования и геоэкологического мониторинга юга Тихоокеанского ландшафтного пояса России (doi:10.18411/1j-05-2020-27), а также по «Ландшафтному звену выстраивания планирования и развития экономических, градостроительных и др. структур осваиваемых территорий» (doi: 10.18411/1j-09-2020-36), и «О необходимости принятия к практической реализации новую ландшафтную стратегию к пространственному развитию геосистемы континент-Мировой океан» (doi: 10.24412/1728-323X-2021-2-36-43).

Объект исследований - Тихоокеанский ландшафтный пояс России, включающий континентальное обрамление и сопряжённые с ним окраинные моря и островные территории (островные дуги) Тихого океана (doi:10.18411/a-2017-089), (https://doi.org/10.18411/a-2017-089) (рис. 1)

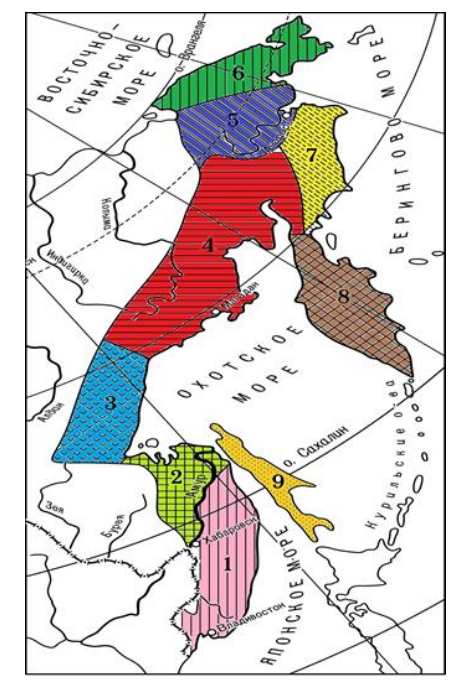

Pис.1. Карта Тихоокеанского ландшафтного пояса России, его областей и окраинньх морей (Старожилов, 2018)

Области пояса: 1. Сихотэ-Алинская; 2. Нижнеамурская; 3. Приохотская; 4.Кольмская; 5. Анадырьская; 6. Чукотская; 7. Корякская; 8. Камчатско-Курильская; 9. Сахалинская 
Выделен Дальневосточной ландшафтной школой профессора В.Т. Старожилова на основе комплексного ландшафтного подхода в понимании зоны перехода континента к океану, основанном на региональном междисциплинарном синтезе, анализе и оценке компонентов его внутреннего содержания (включает фундамент, рельеф, климат, почвы, растительность, биоценозы) [9,11,12] и применения ландшафтной методологии изучения территорий, на основе учета взаимодействия, взаимообусловленности и взаимопроникновения друг в друга компонентов, на основе изучения ландшафтов в условиях окраинно-континентальной дихотомии, на основе изучения орогенического, орографического, климатического и фиторастительного взаимодействующих между собой факторов. Он имеет базовое значение при природопользовании и решения вопросов экологически чистого пространственного развития геосистемы Восточная Россия - Мировой океан.

Цель публикации - обосновать в Российской науке необходимость на основе применения ландшафтного метода выделять и применять в науке и практике орогенные ландшафтные области, провинции, округа как индивидуальные важные таксоны районирования континентального обрамления Тихого океана, как внутреннее содержание Тихоокеанского ландшафтного пояса, как природные структуры диалектической пары геосистемы континент-Мировой океан; обосновать их базовый комплексный характер как структур ландшафтной основы-модели экологически чистого освоения и использование материалов при решении вопросов пространственного развития системы континент-Мировой океан. Ландшафтные таксоны районирования (округа, провинции, области - как внутреннее содержание Тихоокеанского ландшафтного пояса) рассматривать как единицы природного «фундамента» для построения гармонизированных с континентальной природой и океаном региональных и планетарных научных и практик-моделей освоения (краеведческих, экологических, сельскохозяйственных, экономических, социальных, градостроительных и других) к пространственному развитию территорий.

В целом при районировании континентальной части Тихоокеанского ландшафтного пояса геосистемы Восточная Россия - Мировой океан выделяются ландшафтные округа, провинции, области. Это делается на среднемасштабном уровне.

При этом под ландшафтом, ландшафтными округом, провинцией, областью, поясом понимается:

Под ландшафтом понимается природное тело, имеющие высотную (верхнюю), глубинную (нижнюю) и горизонтальную (площадную) границы, с внутренним содержанием взаимосвязанных, взаимообусловленных и взаимопроникающих друг в друга компонентов (фундамент, рельеф, климат, почвы, растительность, биоценозы) с дифференциацией, подчиняющейся высотной и широтной зональности, и организованных ответственными за них орогеническим, орографическим, климатическим, фиторастительным факторами в определенных зональных и азональных условиях в каждый момент своего существования.

Под ландшафтным округом понимается обособленная внутри провинции структура, включающая ландшафты и их виды с дифференциацией, подчиняющейся высотной и широтной зональности, и организованных ответственными за них орогеническим, орографическим, климатическим, фиторастительным факторами в определенных зональных и азональных условиях в каждый момент своего существования.

Под ландшафтной провинцией понимается обособленная внутри области структура, включающая ландшафты подклассов и родов, определяемые высотностью, типами растительности, рельефом и вещественными комплексами фундамента, с дифференциацией, подчиняющейся высотной и широтной зональности и организованных ответственными за них орогеническим, орографическим, климатическим, фиторастительным факторами в определенных зональных и азональных условиях в каждый момент своего существования. 
Под ландшафтной областью понимается обособленная внутри пояса структура, включающая ландшафты одного класса, связанные с крупными тектоническими единицами и орографическими элементами (горными структурами, низменностями) одного зонального или азонального типа и по этому признаку является частью определенной зоны, подчиняющейся высотной и широтной зональности, и организованных ответственными за них орогеническим, орографическим, климатическим, фиторастительным факторами в определенных зональных и азональных условиях в каждый момент своего существования.

Под ландшафтным поясом понимается - азональный пояс ландшафтной сферы с генетически единым структурно-тектоническим положением в зоне окраинноконтинентальной дихотомии системы океан-континент и характеризующегося аккреционной природой фундамента ландшафтных (в Российской части пояса СихотэАлинской, Нижнеамурской, Приохотской, Сахалинской, Камчатско-Курильской, Чукотской и др.) географических областей (структур) с климатическим и растительным внутренним содержанием, подчиняющимся высотной и широтной зональности и эволюционирующим под действием взаимодействующих, взаимосвязанных и взаимопроникающих друг в друга орогенического, орографического, климатического и фиторастительного факторов в определенных зональных и азональных условиях в каждый момент своего существования.

Материалы и методы. Практическая реализация решения районирования территорий определяется многими факторами и зависит от выбора принципов и методов районирования. Выбор тех или иных принципов в каждом конкретном случае зависит от задачи районирования, принятого понятийного аппарата, разработанных частей моделей объекта и самой процедуры районирования, поскольку именно согласно по принципам осуществляется своего рода переход от теоретических представлений по дифференциации территории к практическому осуществлению районированию природы территорий. Принципы и методы районирования, используемые географами, анализируются и представлены в сводных работах Н.И. Михайлова ([4] и др.), Ф.Н. Милькова ([3] и др.), В.Б. Сочавы [8], В.С. Михеева [5], А.Ю. Ретеюм [6], В.И. Булатова, Н.О. Игенбаевой [1] и других. По этим данным основными принципами физико-географического районирования служат: принцип систематики, территориальной общности - дополняется принципами однородности и взаимосвязи таксонов, генетический, комплексности.

В данной статье применяется общая методологическая основа исследования ландшафтный подход, в котором ландшафтному анализу подвергаются геосистемы различных рангов и в конечном итоге дается та или иная географическая оценка ландшафтного пространства объекта исследования, а полученные результаты анализа, синтеза и оценки применяются для решения задачи районирования территорий. Используется также генетический принцип, вытекающий из представления о генетическом единстве (однородности) территории, является важнейшим принципом комплексного физико-географического районирования территории [3]. По А.А. Григорьеву, «общность характера развития территории должна быть положена в основу районирования на всех ступенях районной лестницы» [2]. А.Г. Исаченко и Н.А. Солнцев генетическую однородность или обособленность считают важнейшим диагностическим признаком ландшафта. Генетический принцип применяется в практике физико-географического районирования давно, начиная со второй половины XIX в. и историческое его применение отмечалось неоднократно. Здесь же отметим высказывание словами Ф.Н. Милькова «генетическим единством обладают все категории региональной таксономической лестницы от района до зоны и страны включительно. И это генетическое единство всех единиц выражается в общности истории развития и формирования основных существенных черт ландшафта данной градации». При этом «главной причиной, определяющей обособление и дальнейшее формирование физико-географических единиц всегда является геологогеоморфологическая основа» [7]. Поэтому, учитывая опыт по районированию 
территорий России, в авторских исследованиях мы основывались на представлениях генетического своеобразия развития территории Тихоокеанского ландшафтного пояса России с учетом установленных нами глубинных корней окраинно-континентальной дихотомии, законе фундаментального дуализма суши и моря, парности в организации и функционировании, единстве и противоположности приморских и континентальных ландшафтов и геосистем. Исследования определили, что в горных геосистемах в условиях окраинно-континентальной дихотомии возрастает роль анализа тектоники и вещественного состава. Тектонический режим определяет потенциал динамики и стабильности, а вещественные комплексы, являясь поставщиками материала (геохимического, минерального и т. д.), характеризуют вещественно-материальный потенциал геосистем. Речь идет о направляющем геологическом потенциале развития ландшафтов, о геологическом качестве, которое понимается как способность фундамента ландшафтов за счет собственного геологического природного потенциала в течение длительного времени сохранять и поддерживать динамику развития и вещественно-геохимический потенциал территории. В целом в результате применения генетического принципа при проведении исследований установлено направляющее значение геологического потенциала развития ландшафтов, в обособлении и дальнейшем формировании генетически единых ландшафтных единиц.

Общей методологической основой исследований также используется комплексная основа ландшафтного научно-практического направления, разработанная Дальневосточной ландшафтной школой профессора В.Т. Старожилова, направленного на рациональное освоение и использование территорий, минимизацию глобальных и региональных последствий изменения природы и общества, поиск и внедрение инновационных подходов в устойчивом, экологически сбалансированном и безопасном развитии обширного региона. Основанной на анализе, синтезе и оценке не только теоретических результатов научных исследований, но и практической реализации ландшафтного подхода в различных отраслях производства Тихоокеанского ландшафтного пояса России [9].

При районировании использовалась методология новой ландшафтной стратегии к пространственному развитию геосистемы континент-Мировой океан (doi:10.18411/1j04-2021-23). Это, прежде всего, сформулированные базовые подходы к её разработке на основе современных, прогрессивных результатов ландшафтного научнопрактического направления, разработанного Дальневосточной ландшафтной школой профессора В.Т. Старожилова. Они включают рациональное освоение и использование территорий, минимизацию глобальных и региональных последствий изменения природы и общества, поиск и внедрение инновационных подходов в устойчивом, экологически сбалансированном и безопасном развитии обширного региона и пространственное развитие геосистемы континент-Мировой океан.

Значимым является то, что в основу рассмотрения орогенных таксонов районирования (ландшафтов, округов, провинций, областей), положены многолетние авторские полевые геолого-географические и географические научные и производственные исследования обширной территории окраинной зоны Востока России, которые в свою очередь включают полевые исследования Сихотэ-Алинской, Сахалинской, Камчатской, Анадырской ландшафтных областей $[13,14,16,17,20]$. В целом отметим, что весь полученный полевой и научный материал по ландшафтам анализировался на междисциплинарном уровне, осмысливался и формулировался и благодаря этому была определена научная и практическая географическая целостность континентального обрамления и сопряженных с ним окраинных морей Тихого океана, выделенных орогенных таксонов районирования Тихоокеанского ландшафтного пояса и важность их для выполнения задач освоения высотного обрамления и окраинных морей Тихого океана. При обосновании применения материалов по таксонам районирования при освоении окраинно-континентальной переходной зоны к океану использовались материалы практической реализации ландшафтного подхода с применением ландшафтной индикации в различных областях 
природопользования $[10,15,18,19]$. Особо отметим, что для определения региональной и планетарной ландшафтной целостности таксонов ландшафтов, как структурных единиц Тихоокеанского ландшафтного пояса соизмеримых с фокусом максимального взаимодействия океана и Азиатского континента, применены материалы авторских палеогеографических исследований. Применены результаты геологических и палеогеографических реконструкций по установлению генезиса, состава и тектонической эволюции фундамента ландшафтов. Применялась авторская концепция геодинамической эволюции зоны перехода Азиатского континента к океану.

Использовались материалы, полученные по итогам многочисленных экспедиций на Сахалине, Камчатке, Чукотке и других территориям и, в частности, новые векторнослоевые картографические материалы по отдельным регионам зоны континентального обрамления (сихотэ-алинской, сахалинской и др. ландшафтным областям). При обосновании применения материалов по орогенным ландшафтам ландшафтного пояса как основ - моделей при освоении окраинно-континентальной переходной зоны к океану использовались материалы практической реализации ландшафтного подхода с применением ландшафтной индикации в различных областях природопользования, материалы по организации и структурам ландшафтов и профилям через континентальное обрамление, в которых отражено установленное нами внутреннее содержание ландшафтов территории пояса в системе ландшафт, вид, род, подкласс, класс, округ, провинция, область, пояс, а также частные материалы по орогенным таксонам ландшафтов Тихоокеанского ландшафтного пояса России (DOI: 10.35735/tig.2021.17.72.023, DOI: 10.18411/lj-03-2021-33). Использовался материал по выделенным высотно-ландшафтным комплексам горных, островных, озерных геосистем, а также их водосборов (DOI: 10.24411/9999-039A-2020-10075).

Весь имеющийся материал анализировался на основе сопряженного анализа и синтеза межкомпонентных и межландшафтных связей с учетом окраинноконтинентальной дихотомии и данных по орогеническому, орографическому, климатическому и фиторастительному факторам формирования географически единых территорий. Получены были следующие результаты.

Результаты. При познании, формулировании возможностей и необходимости применения материалов по орогенным ландшафтам континентального обрамления Тихого океана как таксонов планетарной Тихоокеанской ландшафтной геосистемы в освоении Мирового океана получен фундаментальный результат настоящих исследований, заключающийся в том, что для реализации рассмотрения возможностей и необходимости применения материалов по рассматриваемым таксонам континентального обрамления Тихого океана в экологически чистом освоении необходимо иметь прежде всего оцифрованную векторно-слоевую морфологическую ландшафтную основу [9]. Такие основы, как в целом по поясу, так и по его отдельным регионам получены (Сихотэ-Алинской, Сахалинской ландшафтным областям и др.). Это, прежде всего, оцифрованные векторно-слоевые морфологические ландшафтные модели (векторно-слоевые ландшафтные карты), которые на цифровом уровне дают знание строения географического пространства рассматриваемого объекта. Этот результат позволяет проанализировать территории по оцифрованным выделам ландшафтов. Сравнить внутреннее содержание не только рассматриваемых в работе таксонов, но и таких таксонов как ландшафт, вид, род, подкласс, класс, тип, округ, провинция, область, пояс. Затем решать задачи по практикам природопользования. Тем более, что результат включает современное компьютерное программное обеспечение.

Синтез, анализ обеспеченности орогенных ландшафтов континентального обрамления Тихого океана современными векторно-слоевыми картографическими материалами, составленными на основе современных требований картографии и математического обеспечения, показывает следующую общую картину такой обеспеченности. Составлены карты и объяснительные записки к ним: 
1. Карта ландшафтов Тихоокеанского ландшафтного пояса, областей и прилегающих морей в масштабе 1: 3000000 (автор Старожилов В.Т.). На карте также выделены ландшафтные области: Сихотэ-Алинская, Нижнеамурская, Приохотская, Колымская, Анадырская, Чукотская, Корякская, Камчатско-Курильская, Сахалинская. Представлены сопряженные с областями окраинные моря исследования.

2. Ландшафтная карта Приморского края масштаба 1:1 000000 (автор Старожилов В.Т., сжатая версия электронной карты ландшафтов Приморского края масштаба 1:500 000);

3. Карта ландшафтного районирования Приморского края масштаба 1:1 000000 (автор Старожилов В.Т.). Выделено 54 округа, 8 провинций, 4 области;

4. На основе базовой карты ландшафтов Приморского края (на карте картографировано 3156 выделов ландшафтов), так как она цифровая, то было получено отдельных 3156 карт по всем выделенным на карте выделам ландшафтов. На основе карты районирования, так как она цифровая векторно-слоевая, то было получено отдельных 66 карт ландшафтных единиц районирования;

5. Впервые для АТР издана (автор Старожилов В.Т.) объяснительная записка к карте ландшафтов Приморского края масштаба 1: 500 000. В ней описано 3156 выделов ландшафтов;

6. На основе основной векторно-слоевой карты ландшафтов Приморского края составлены частные векторно-слоевые карты ландшафтов и высотно-ландшафтных комплексов островных, озерных и горных водосборов Тихоокеанского ландшафтного пояса, в том числе составлена карта ландшафтов и высотно-ландшафтных комплексов водосбора озера Ханка;

7. Ландшафтная карта острова Сахалин в масштабе 1 : 500000 . В настоящее время карта и объяснительная записка к ней готовятся к изданию;

8. Ландшафтная карта урочищ и групп урочищ о. Русский и прилегающих к нему островов Владивостокского городского округа масштаба 1: 25000 ;

9. Карта положения и эволюции палеоструктур и сопряженных с ними элементов зоны перехода северо-востока Азии к Тихоокеанской плите.

Карты представляются значимым академическим творением в сфере цифровых карт, основанном на огромном опыте изысканий в области теории, а также практике ландшафтоведения, и вплоть до этих пор в части обзорности и содержательности не имеет аналогов для территории Азиатско - Тихоокеанского региона (АТР), охватывая Азиатские государства. Карты принадлежат к картам новейшего поколения, в которых в перспективе станут отображать в цифровом виде не отраслевые слои компонентов, но слои классификационных единиц ландшафтов. Немаловажно в таком случае то, что карты нацелены на практическую реализацию ландшафтного подхода в освоении земель, а также способны быть применены как естественные модели «фундамент» с целью формирования гармонизованных с природой экологических, гидрологических, экономических, социальных и др. моделей освоения территорий.

Важно отметить, что вышеотмеченные карты в масштабе 1: 500 000, 1; 1000 000, 1: 3000000 и др. континентального обрамления Тихого океана по Тихоокеанскому ландшафтному поясу и отдельно по его областям (Сихотэ-Алинской, Сахалинской, Камчатской и др.) составлены в разработанной Дальневосточной ландшафтной школой профессора В.Т. Старожилова системе ландшафт, вид, род, класс, тип, округ, провинция, область, пояс. Разработанные и сформулированные классификации и объяснительные записки к картам частично изданы в открытой печати. Кроме того через орогенные ландшафты континентального обрамления Тихого океана составлены 
ландшафтные профили. На них кроме ландшафтов выделены и показаны высотноландшафтные комплексы.

В целом по результатам синтеза, анализа и оценки всех имеющихся материалов и в том числе полевых исследований автора (30 полевых сезонов) Сихотэ-Алинской, Сахалинской, Камчатской, Анадырской ландшафтных территорий установлены ландшафтные особенности континентального обрамления Тихого океана. Весь полученный статистический научный и полевой материал систематизирован, проведено ландшафтное районирование и в Тихоокеанском ландшафтном поясе России выделены ландшафтные области (рис. 1), провинции, округа (таблица 1).

Примеры областей, провинций Тихоокеанского ландшафтного пояса России

\begin{tabular}{|c|c|c|}
\hline Пояс & Область & Провинция \\
\hline \multirow{3}{*}{ 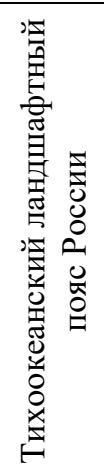 } & $\begin{array}{c}\text { Сихотэ-Алинская (в границах } \\
\text { Приморского края) }\end{array}$ & $\begin{array}{c}\text { 1.Самаргинская; 2. Северо-Сихотэ-Алинская; } 3 . \\
\text { Восточно- Сихотэ-Алинская; 4. Центрально- } \\
\text { Сихотэ-Алинская; 5. Западно- Сихотэ-Алинская; } \\
\text { 6. Западно-Приморская равнина; 7. Восточно- } \\
\text { Маньчжурская; 8. Южно-Приморская; }\end{array}$ \\
\hline & Сахалинская & $\begin{array}{c}\text { 1.Западно-Сахалинская; 2. Центрально- } \\
\text { Сахалинская; 3. Восточно-Сахалинская; } 4 . \\
\text { Северо-Сахалинская; }\end{array}$ \\
\hline & Камчатско-Курильская & $\begin{array}{c}\text { 1.Западно-Камчатская; 2.Срединно-Камчатская; } \\
\text { 3.Центрально-Камчатская; 4. Восточно- } \\
\text { Камчатская; }\end{array}$ \\
\hline
\end{tabular}

Ниже, как пример, приводится описание особенностей провинций СихотэАлинской, Сахалинской и Камчатской ландшафтных областей Тихоокеанского ландшафтного пояса.

В Сихотэ-Алинской ландшафтной области (в границах Приморского края) выделяются провинции: Самаргинская, Северо-Сихотэ-Алинская, Восточно- СихотэАлинская, Центрально- Сихотэ-Алинская, Западно- Сихотэ-Алинская, ЗападноПриморская равнина, Восточно-Маньчжурская, Южно-Приморская; (рис. 2). Приводится описание наиболее осваиваемых Западно-Приморской равнины, ВосточноМаньчжурской, Южно-Приморской провинций.

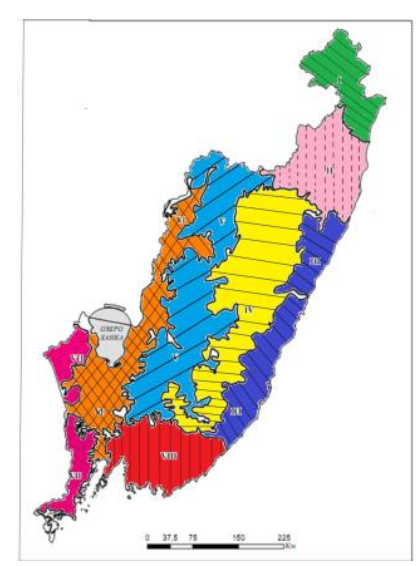

Рис. 2. Ландшафтные провиничи Сихотэ-Алинской ландшафтной области (в границах Приморского края): I-Самаргинская, II -Северо-Сихотэ-Алинская, III-Восточно-Сихотэ-Алинская, IV-

Центрально-Сихотэ-Алинская, V-Западно-Сихотэ-Алинская, VI-Западно-Приморская равнина, VIIВосточно-Маньчжурская, VIII - Южно-Приморская

Западно-Приморская равнина. Провинция занимает пространство между Сихотэалинской и Восточно-Маньчжурской горными областями. Включает оз. Ханка и Уссури-Ханкайскую равнину с бассейнами рек Мельгуновка, Комиссаровка, Илистая, Белая, среднее течение р. Уссури, нижнее течение р. Большая Уссурка и др. Включает 
равнинную территорию дальневосточного равнинного класса ландшафтов с характерным для нее сочетанием ландшафтов лесостепного равнинного и долинноречного подкласса и равнинного эрозионно-аккумулятивного и долинно-речного и приморско-равнинного родов, различных лесных видов с широколиственномелколиственно-смешанными, долинными широколиственными с липами, кленом и дубом, редколесно-порослево-дубовых, мелколиственных вейниково-осоковых, луговых осоко-вейниковых на лугово-бурых, бурых лесных, задернованных дерновоторфянисто-глеевых, луговых пойменных и болотных почвах. Доминантными являются местности с четвертичными аллювиально-озерными (мощность от 1,0 до 60 м) и гранитоидными, сланцевым, карбонатно-гнейсовым и другими комплексами фундамента.

Фундамент сложен палеозойскими сланцевым, гнейсово-сланцевым, сланцевокарбонатным, кремнисто-карбонатным, алевролито-песчаниковым и гранитоидным вещественными комплексами. Фундамент перекрыт мощным чехлом четвертичных озерно-аллювиальных отложений и залегает на глубине до 110 м в районе оз. Ханка. В направлении от озера к внешним границам провинции глубина залегания уменьшается до 15 - 20 м.

Восточно-Маньчжурская ландшафтная провинция включает ВосточноМаньчжурскую складчатую горную территорию дальневосточного горного класса ландшафтов с характерными для нее горно-лесным смешанно-широколиственным классом, низкогорным вулканогенно-терригенным родом и видами ландшафтов с широколиственными группировками растительности на бурых лесных и других почвах, развивающимися в условиях западного грабен-горстового борта Амуро-Уссурийской рифтогенной структуры. По внутреннему содержанию делится на три морфологически самостоятельные части: к северу от долины р. Раздольная располагается Пограничный горный район, к югу - Борисовское базальтовое плато и Хасанско-Барабашский горный район.

Южно-Приморская провинция расположенна в южной части Сихотэ-Алинской области, в басс. рек Шкотовка, Киевка, Партизанская и др. Включает горную территорию дальневосточного горного класса ландшафтов с характерным для нее сочетанием ландшафтов горно - смешанно-широколиственного и горно-темнохвойного подклассов, массивно-и расчлененносреднегорных полисубстратных, низкогорных терригенного и вулканогенно-терригенного родов. Характеризуется сменой поясов: доминантный смешанно-широколиственный сменяется темнохвойным. Фундамент сложен метаморфическим, метагабброидным комплексами, прорванными гранитами зон активизации.

В Сахалинской ландмафтной области выделяются провинции: горные Восточно-Сахалинская и Западно-Сахалинская, равнинные Центрально-Сахалинская и Северо-Сахалинская (рис. 3).

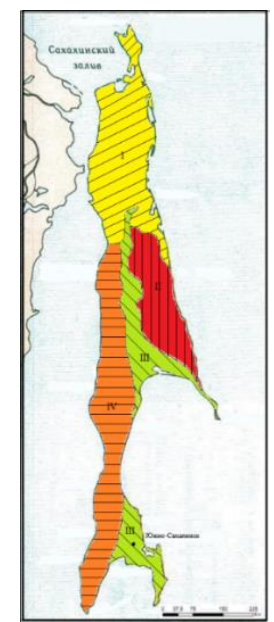

Рис.3. Ландшафтные провинциии острова Сахалин: I-Северо-Сахалинская; II-Восточно-Сахалинская; IIIЦентрально-Сахалинская; IV-Западно-Сахалинская. 
Восточно-Сахалинская ландшафтная горная провинция включает ВосточноСахалинскую складчатую горную территорию дальневосточного горного класса ландшафтов и гольцовые и подгольцовые полисубстратные, среднегорные, низкогорные и горно-долинные полисубстратные, терригенные и вулканогеннотерригенные роды и горно-темнохвойные и другие подклассы и виды ландшафтных геосистем. Это среднегорная, с крутыми склонами и острыми вершинами территория. Фундамент сложен алевролит-песчаниковым с телами кислого, основного и ультраосновного состава вещественным комплексом

Западно-Сахалинская ландшафтная горная провинция включает ЗападноСахалинскую складчатую горную территорию дальневосточного горного класса ландшафтов с доминантным темнохвойным подклассом, низкогорным терригенным родом и видами ландшафтов с доминантными темнохвойными группировками растительности на бурых лесных и других почвах. Это среднегорная, с крутыми склонами и острыми вершинами территория. Фундамент сложен алевролитпесчаниковым с телами кислого состава вещественным комплексом.

Центрально-Сахалинская ландшафтная равнинная провинция включает Центрально-Сахалинскую равнину (располагается между Восточно-Сахалинскими и Западно-Сахалинскими горами), темнохвойные равнинные и долинно-речные ландшафтные геосистемы Томь-Поронайской низменности с темнохвойными лесами на буро-таежных почвах, с лугами, болотами, марями с болотно-торфяными и пойменными лугово-дернованными почвами. Представлена эррозионно-аккумулятивным и озерным равнинным и долинно-речным родами ландшафтов.

Северо-Сахалинская ландшафтная равнинная провинция занимает СевероСахалинская равнину и включает районы западного побережья, центральную часть и восточного побережья. Ландшафты западного побережья включают полосу низких морских террас сложенных песками, Это слабо всхолмлённая, с дюнами, заболоченная на пониженных местах равнина с лиственничным редколесьем и кедровым стлаником. Ландшафты центральной части занимают большую часть области, представляет собой приподнятую, всхолмленную равнину с болотами, гарями, редколесьем лиственницы и зарослями кедрового стланика. Ландшафты восточного побережья включают узкую полосу песчаных морских террас, кос и пересыпей с обширными лагунами с редкими редколесьями лиственницы и кедрового стланика.

В Камчатско-Курильскаой ландшафтной области выделяются ландшафтные горные и равнинные провинции: равнинная Западно-Камчатская, горная СрединноКамчатская, равниная Центрально-Камчатская, горная Восточно-Камчатская (рис. 4).

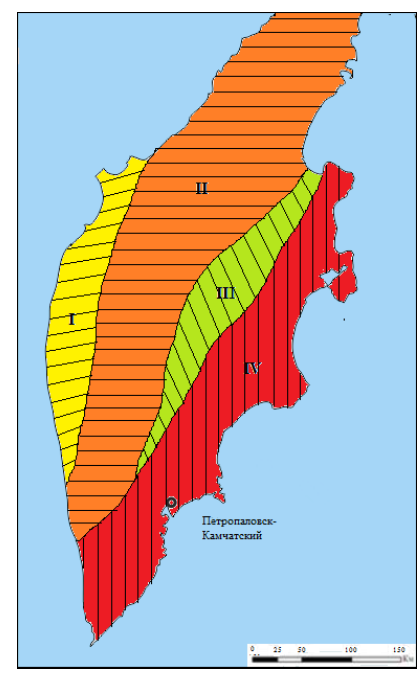

Рис.4 Ландшафтные провиничи полуострова Камчатка: I-Западно-Камчатская; II-СрединноКамчатская; III-Центрально-Камчатская; IV-Восточно-Камчатская. 
Западно-Камчатская ландшафтная равнинная провинция занимает ЗападноКамчатскую равнину и включает районы западного побережья. Представлена равнинным классом ландшафтов с характерным для нее сочетанием тундровых ландшафтов равнинного и долинно-речного подкласса и равнинного эрозионноаккумулятивного и долинно-речного и приморско-равнинного родов, различных заболоченных травянисто - лесных видов с зарослями водянки и голубики и клюквой, увалистых каменноберезовых травянистых лесных и редколесных, в предгорьях с обогащением злаково-папортниковым высокотравием, долинных тополево-чозениевых лесов чередующихся с разнотравными лугами с преобладающими перегнойными почвами

Срединно-Камчатская ландшафтная горная провинция занимает СрединноКамчатский горный район и включает горную территорию Срединного Камчатского хребта. Представлена горным классом ландшафтов, гольцовым, высокогорным вулканогенным, среднегорным полисубстратным и низкогорным полисубстратным родами и видами ландшафтов с елово-лиственничными группировками растительности на различных почвах, с каменноберезовыми лесами, виды с зарослями кедрового стланика и кустарниковой ольхи, виды горных тундр и альпийских лугов с кустарничками рододендрона, а также долинно-речные с тополями, чозении, зарослями кустарниковой ивы. Преобладающие высоты вершинного уровня 1500-2000м, Наиболее высокая - Ичинская Сопка - высотой 3607 м.

Центрально-Камчатская ландшафтная равнинная провинция занимает Центрально-Камчатский равнинный район и включает равнинную территорию с юга от верховьев р. Быстрой до берегов Карагинского залива, охватывая сопряженные равнинные и котловинные структуры, крупнейшая из которых занимает долину р. Камчатка. Представлена равнинным классом ландшафтов с характерным для нее сочетанием тундровых ландшафтов равнинного и долинно-речного подкласса и равнинного эрозионно-аккумулятивного и долинно-речного родов, различных заболоченных травянисто - лесных видов с редколесно-кустарниковыми зарослями, видов редколесий из каменной березы и кустарниковой ольхи, на возвышенных участках видов с зарослями кедрового стланика, вида с хвойными лесами из лиственницы курильской и ели аянской с участием каменной березы и кедрового стланика. На водоразделе р. Камчатка и Быстрая и в истоках р. Камчатка развиты виды ландшафтов с травянистыми лесами из каменной березы и лесолуговые с участием белой березы.

Восточно-Камчатская ландмафтная горная провинция занимает ВосточноКамчатский горный район и включает горную территорию Восточных хребтов и Восточно-Камчатской высокогорной ледниково-вулканической системы. Здесь расположены вулканические группы: Карымская, Семячинская, Жупановская, Кроноцкая, Корякская. Представлена горным классом ландшафтов; горнотундровым, лесолуговым, горно-лесным подклассом; гольцовым, высокогорным вулканогенным, среднегорным полисубстратным и низкогорным полисубстратным родами и видами ландшафтов с парковыми высокотравными лесами из березы Эртмана, видом с кустарниковыми зарослями из кедрового стланика и кустарниковой ольхи; видом с лесами из лиственницы камчатской с багульником и кедровым стлаником; видом с лесами из каменной и белой берез; эрозионно-долинными видами кустарниковоразнотравными белоберезовиками с ольхой пушистой; видом с лесами из чозении, тополя Комарова и черемухи азиатской с подлеском с шиповником, жимолостью съедобной, рябиной бузинолиственной. С высоты 800-1000м начинают преобладать виды ландшафтов с зарослями кедрового стланика и кустарниковой ольхи. Верхние части склонов представлены видами с горнотундровыми группировками и альпийскими лугами, а на каменистых склонах формируются лишайниковые тундры. 
Заканчивая характеристику примеров таксонов ландшафтов важно отметить, что, как показали исследования Тихоокеанского ландшафтного центра ДВФУ в освоении геосистемы континент-океан, установление статистических данных по таксонам ландшафтов и морфологическому строению территорий- это только первый этап ландшафтного изучения Востока России и Тихоокеанского ландшафтного пояса. Специальное изучение ландшафтной школой профессора В.Т. Старожилова фундаментальных направлений изучения ландшафтов и их картографирования установлено то, что кроме морфологического направления выделяются: индикационное, ландшафтных узловых структур освоения, планирования и проектирования. Отмечается, что все они сопровождаются составлением векторнослоевых разномасштабных индикационных, узловых структур освоения, планирования и проектирования векторно-слоевых ландшафтных карт (doi: 10.18411/1j-09-2020-35). Поэтому для получения полной характеристики объектов освоения фундаментальные исследования территорий должны быть продолжены в отмеченных выше направлениях. Такие работы уже проводятся в Тихоокеанском международном ландшафтном центре ДВФУ под руководством профессора В.Т. Старожилова.

Также подтверждается и отмечается, что применение материалов районирования в освоении геосистемы континент-Мировой океан направлено на рациональное освоение и использование территорий, минимизацию глобальных и региональных последствий изменения природы и общества, поиск и внедрение инновационных подходов в устойчивом, экологически сбалансированном и безопасном развитии обширного региона. Основывается на анализе, синтезе и оценке не только теоретических результатов научных исследований, но и практической реализации ландшафтного подхода в различных отраслях производства Тихоокеанского ландшафтного пояса России.

Заключение. Констатируется, что на основе научных и полевых исследований Тихоокеанского международного ландшафтного центра ДВФУ и Ландшафтной школы профессора Старожилова получен прежде всего фундаментальный статистический и картографический ландшафтный материал по ландшафтному обрамлению Тихого океана. На его основе формулируется и картографируется в ландшафтных границах географически и ландшафтно-целостные таксоны иерархической системы ландшафтов геосистемы континент-Мировой океан: ландшафт, вид, род, подкласс, класс, тип, округ, провинция, область, пояс.

На основе полученных и формулируемых итогов синтеза, анализа и оценки данных установлено, формулируется и утверждается, что в Российской науке необходимо на основе применения ландшафтного метода выделять округа, провинции, области как индивидуальные важные таксоны континентального обрамления Тихого океана. Они выделяются как внутреннее содержание Тихоокеанского ландшафтного пояса, как природные таксоны структур и организации диалектической пары геосистемы континент-Мировой океан. Рекомендуется применять их базовый комплексный характер как таксоны структуры ландшафтной основы-модели освоения и использовать эти материалы как опорный природный «фундамент» к пространственному развитию территорий. Ландшафтные округа, провинции, области рассматривать как единицы природного «фундамента» для построения гармонизированных с континентальной природой и океаном региональных и планетарных научных и практик-моделей освоения: краеведческих, экологических, сельскохозяйственных, туристических, экономических, социальных, градостроительных и других.

$$
* * *
$$

1. Булатов В.И., Игенбаева Н.О. Обь-Иртышский бассейн как геосистема: вопросы теории и практики эколого-географического изучения. - Ханты- Мансийск: Информационно-издательский центр ЮГУ, 2010. - 85с. 
2. Григорьев А.А. Географическая оболочка Земли // Взаимодействие наук при изучении Земли. M., 1963. - $164 \mathrm{c}$.

3. Мильков Ф.Н. Ландшафтная география и вопросы практики. - М.: Изд-во «Мысль», 1966. -256 с.

4. Михайлов Н.И. Избранные лекции по физико-географическому районированию. Геогр. фак. Моск. Ун-та. М., 1955.

5. Михеев В.С. Ландшафтный синтез географических знаний. - Новосибирск: Наука, 2001. -215 с.

6. Ретеюм А.М. Исследовательские установки ландшафтоведения / Ландшафтоведение: теория, методы, региональные исследования, практика // Мат-лы XI межд. Ландш. Конф. - М.: Геогр. фак. МГУ, 2006. - С46-49.

7. Солнцев Н.А. Учение о ландшафте (избранные труды). - М.: Изд-во МГУ, 2001. - 384 с.

8. Сочава В.Б. Принципы физико-географического районирования. «Вопросы географии» Сб. статей для XVIII Междунар. Геогр. конгресса. М-Л., 1956.

9. Старожилов В.Т. Природопользование: практическая ландшафтная география. / учебник. Школа естественных наук ДВФУ, Тихоокеанского международного ландшафтного центра, Школа естественных наук ДВФУ. Владивосток, 2018. 276с

10. Старожилов В.Т. Эколого-ландшафтный подход в формировании региональной экологической политики на территории стран АТЭС / В сборнике: Шестые Гродековские чтения. Актуальные проблемы исследования Российской цивилизации на Дальнем Востоке. межрегиональная научнопрактическая конференция. Правительство Хабаровского края. Хабаровск, 2009. С. 24-28.

11. Старожилов В.Т. Региональные особенности компонентов и факторов структуры организации ландшафтов юга Дальнего Востока (на примере Приморского края). - Владивосток, 2007.

12. Старожилов В.Т. Структура и пространственная организация ландшафтов юга Дальнего Востока (на примере Приморского края). - Владивосток. 2007.

13. Старожилов В.Т., Зонов Ю.Б. Ландшафтные предпосылки устойчивого развития территорий. / В сборнике: Природа без границ. Материалы I Международного экономического форума. Администрация Приморского края. 2006. С. 261-265.

14. Старожилов В.Т. Окраинно-континентальный ландшафтный пояс как географическая единица Тихоокеанской России / В сборнике: Устойчивое природопользование в прибрежно-морских зонах. Материалы международной конференции. 2013. С. 38-42.

15. Старожилов В.Т., Крупская Л.Т., Дербенцева А.М., Черенцова А.А., Степанова А.И., Ткаченко В.И., Матвеенко Т.И. Денудационные процессы в ландшафтах и геоэкологические предпосылки техногенных изменений // Министерство образования и науки Российской Федерации, Федеральное агентство по образованию, Дальневосточный государственный университет, Тихоокеанский государственный университет, Институт горного дела ДВО РАН. Владивосток, 2009.

16. Старожилов В. Т. Картирование ландшафтов и геодинамическая эволюция фундамента Дальневосточных территорий/ В. Т. Старожилов // Ноосферные изменения в почвенном покрове: материалы Международной научн. конф. Дальневост. гос. ун-т: Под общей редакцией: А.М. Дербенцева. 2007. С. 174-178.

17. Старожилов В.Т., Дербенцева А.М., Ознобихин В.И., Крупская Л.Т., Степанова А.И. Ландшафтные условия развития эрозионно-денудационных процессов юга Дальнего Востока. Владивосток, 2008.

18. Старожилов В.Т. Эколого-ландшафтный подход к промышленным территориям юга Дальнего Востока // В сборнике: Современные геофизические и географические исследования на Дальнем Востоке России. материалы 9-й научной конференции, Владивосток: конференция приурочена к Всемирным дням воды и метеорологии, а также к 110-летию ДВГУ и 45-летию ГФФ. Дальневосточный государственный университет, Институт окружающей среды ; под редакцией $\mathrm{H}$. В. Шестакова. Владивосток, 2010. С. 155-158.

19. Старожилов В.Т. Проблемы ресурсопользования, структура и пространственная организация ландшафтов приокеанских Дальневосточных территорий // В сборнике: Науки о Земле и отечественное образование: история и современность. материалы Всероссийской научнопрактической конференции, посвященной памяти академика РАО А. В. Даринского. Российский государственный педагогический университет им. А. И. Герцена, факультет географии. 2007. С. 310-312.

20. Старожилов В. Т. Ландшафтные геосистемы Сахалинского звена Тихоокеанской России // В сборнике: Научная дискуссия: гуманитарные, естественные науки и технический прогресс. Материалы VII Всероссийской научно-практической конференции. 2015. С. 54-64. 